\title{
Clinical, morphogical and immunohistochemical aspects of oral inflammatory myofibroblastic tumor: a rare case report in a pediatric patient
}

\author{
Aspectos clínicos, morfológicos e imuno-histoquímicos do tumor miofibroblástico inflamatório oral: relato de \\ caso raro em paciente pediátrico
}

\author{
Aspectos clínicos, morfológicos e inmuno-histoquímicos del tumor miofibroblástico inflamatorio oral: reporte de \\ caso raro en paciente pediátrico \\ Hellen Bandeira de Pontes SANTOS ${ }^{1}$ \\ Natália Guimarães BARBOSA ${ }^{1}$ \\ Tiago João da SILVA FILHO 1 \\ Lélia Maria Guedes QUEIROZ ${ }^{1}$ \\ Alberto GURGEL ${ }^{2}$ \\ Roseana de Almeida FREITAS ${ }^{1}$ \\ Patrícia Teixeira de OLIVEIRA ${ }^{\mathbf{1}}$
}

${ }^{1}$ Programa de Pós-Graduação em Patologia Oral, Universidade Federal do Rio Grande do Norte, Departamento de Odontologia 59056-000 Natal-RN, Brasil ${ }^{2}$ Universidade Potiguar, Departamento de Odontologia 59056-000 Natal-RN, Brasil

\begin{abstract}
Inflammatory myofibroblastic tumor (IMT) is a rare benign neoplasm composed by myofibroblasts and fibroblasts admixed with inflammatory cells. Here, we report a case of IMT in the oral cavity of left mandible of a 12-year-old boy. Histopathological investigation revealed a proliferation of fibroblasts and myofibroblasts (positive for alpha-smooth muscle actin and vimentin) associated with inflammatory cells. The patient is still under follow-up and without evidence of recurrence. Oral IMT is a challenge for the clinician in diagnosis due to the nonspecific clinical presentation. Thus, histology and immunohistochemistry are required to reach an accurate diagnosis of this lesion.
\end{abstract}

Descriptors: Neoplasms; Diagnosis; Immunohistochemistry.

\section{Resumo}

O tumor miofibroblástico inflamatório (TMI) é uma neoplasia benigna rara composta por miofibroblastos e fibroblastos associados com células inflamatórias. Aqui, relatamos um caso de TMI na cavidade oral da mandíbula esquerda de um menino de 12 anos. A análise histopatológica revelou uma proliferação de fibroblastos e miofibroblastos (positivos para alfa-actina de músculo liso e vimentina) associados à células inflamatórias. O paciente ainda está sob acompanhamento e sem evidências de recorrência. O TMI oral é um desafio diagnóstico para o clínico devido à apresentação clínica não específica. Assim, análises histopatológicas e imuno-histoquímicas são necessárias para alcançar um diagnóstico preciso dessa lesão.

Descritores: Neoplasias; Diagnóstico; Imuno-Histoquímica.

\section{Resumen}

El tumor miofibroblástico inflamatorio (TMI) es una neoplasia benigna rara compuesta de miofibroblastos y fibroblastos asociados con células inflamatorias. Aquí, relatamos un caso de TMI en la cavidad oral de la mandíbula izquierda de un niño de 12 años. El análisis histopatológico reveló una proliferación de fibroblastos y miofibroblastos (positivos para alfa-actina de músculo liso y vimentina) asociados a las células inflamatorias. El paciente todavía está bajo seguimiento y sin evidencias de recurrencia. El TMI oral es un desafío diagnóstico para el clínico debido a la presentación clínica no específica. Así, los análisis histopatológicos e inmuno-histoquímicos son necesarios para alcanzar un diagnóstico preciso de esa lesión.

Descriptores: Neoplasias; Diagnóstico; Inmunohistoquímica.

\section{INTRODUCTION}

Inflammatory myofibroblastic tumor (IMT) is an uncommon benign lesion composed by spindleshaped fibroblasts or myofibroblasts. It also contains a varying number of chronic inflammatory cells, mainly plasma cells and lymphocytes ${ }^{1-3}$. This lesion was first described in 1905 as being an inflammatory pseudotumor (IPT). In 1994, the term inflammatory myofibroblastic tumor (IMT) was felt to be more appropriate. A study by Liston et al. ${ }^{4}$ was the first to report an IMT in the oral cavity ${ }^{3}$.

Although several pathological factors have been suggested (reactive, infectious, autoimmune or neoplastic), the etiology of IMT remains unknown ${ }^{2}$. Despite being a lesion more commonly found in the lungs, extrapulmonary IMT has also been reported in most organs and areas of the body including head and neck $^{1,4,5}$. In the oral cavity, IMT usually presents itself as a hard swelling with very mild systemic symptoms in comparison to when it is found in other organs ${ }^{3}$.

IMT can affect a wide age range varying from 19 months to 63 years, but there is a predilection for children and young adults ${ }^{1}$. The behavior of this tumor is quite variable since it may resemble either reactive lesions or benign neoplasms. Some may indeed grow very aggressively, and display typical characteristics of malignancy ${ }^{2}$. Oral IMT has a nonspecific clinical appearance, and a rapid growth rate both of which can clinically and radiographically be regarded as signs of malignancy. For that reason, this entity deserves comprehensive histopathological evaluation in order to favor a correct diagnosis, and prevent unnecessary radical interventions ${ }^{3}$.

Based on this, the aim of this study was to report a rare case of IMT in the alveolar mucosa which was initially diagnosed as a peripheral giant cell granuloma in a 12-year-old boy patient. The role of immunohistochemistry in diagnosing myofibroblastic lesions, such as the IMT, was also discussed. 


\section{CASE REPORT}

A 12-year-old male patient presented with a painless lump in the lingual alveolar mucosa adjacent to lower first and second molars in the left mandible. The lesion had been first noticed three months ago. It was well circumscribed, pedunculated, the same color as the surrounding mucosa, and with a focal ulceration, but signs of either bleeding or exudates were not present (Figure 1A). The panoramic radiograph showed alveolar bone loss in the lower left first molar and displacement of the lower left second molar (Figure 1B). Both clinical and radiographic diagnoses were of peripheral giant cell granuloma. Excisional biopsy was performed and macroscopic examination revealed a lobular mass of soft tissue measuring approximately $3.5 \mathrm{~cm}$ (Figure 2).

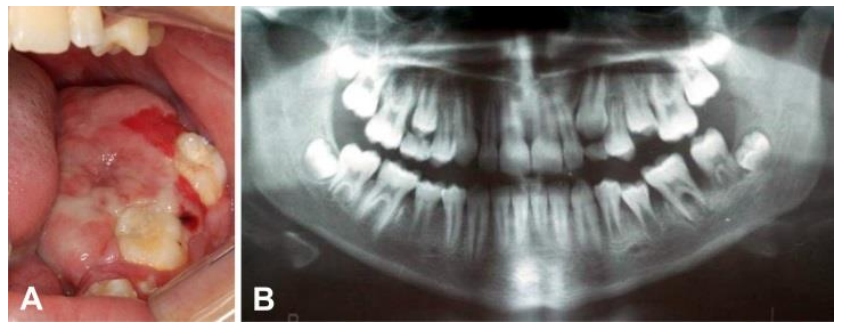

Figure 1: A. Intraoral view showing a mass with exophytic growth and focal ulceration on the alveolar mucosa of the lower left quadrant. B. Panoramic radiograph showing alveolar bone loss in the lower left first molar, and displacement of the adjacent second molar.

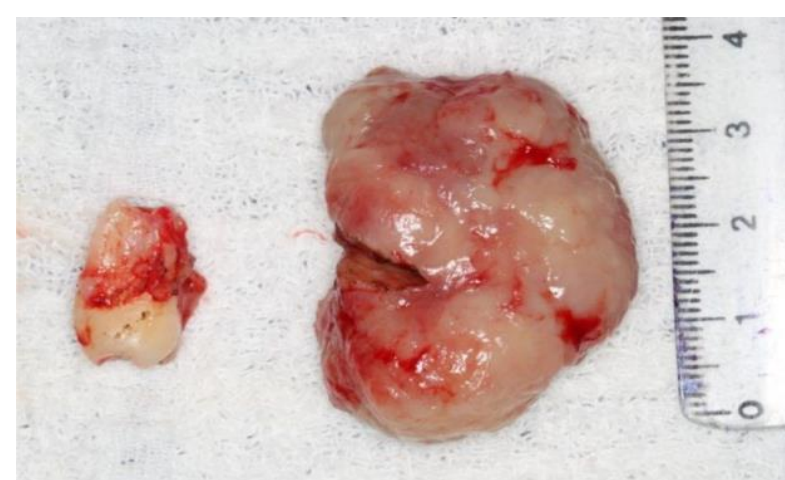

Figure 2: Surgical specimen presenting as a well-circumscribed lobular mass measuring approximately $3.5 \mathrm{~cm}$. The lower left second molar was extracted during surgery.

The lower left second molar was also removed during surgery. Examination of the tissue stained by hematoxylin and eosin showed proliferation of both spindle and rounded cells in a vascularized fibrous tissue containing a chronic inflammatory infiltrate of lymphocytes and plasma cells (Figure 3A-B). Nuclear and cellular atypia or any other sign of malignancy were not observed. The immunohistochemical analysis disclosed spindle cells diffusively and strongly positive for alpha-smooth muscle actin as well as for vimentin (Figure 3C-D). Based on such histopathological and immunohistochemical findings, the diagnosis of IMT was established. The patient is under follow-up and no relapse has been observed after two years (Figure 4A-B).

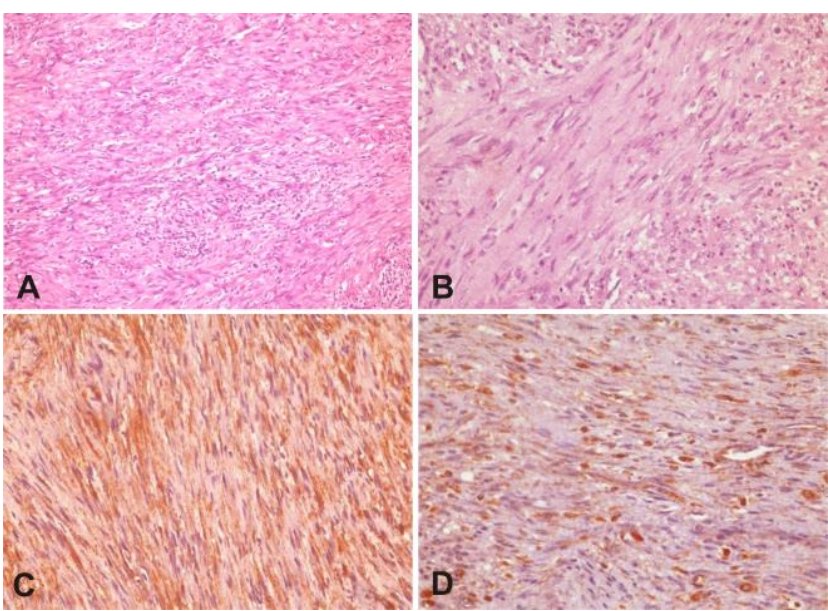

Figure 3: A. Microscopic view of the specimen showing spindle and rounded cells permeated by an inflamed stroma $(\mathrm{H} / \mathrm{E}, 200 \mathrm{X})$. B. Tumor cells in a vascular fibrous stroma containing chronic inflammatory infiltrate $(\mathrm{H} / \mathrm{E}, 400 \mathrm{X})$. C. Immunoreactivity of tumor cells to alpha-smooth muscle actin $(400 \mathrm{X})$. D. Immunoreactivity of tumor cells to vimentin $(400 \mathrm{X})$.

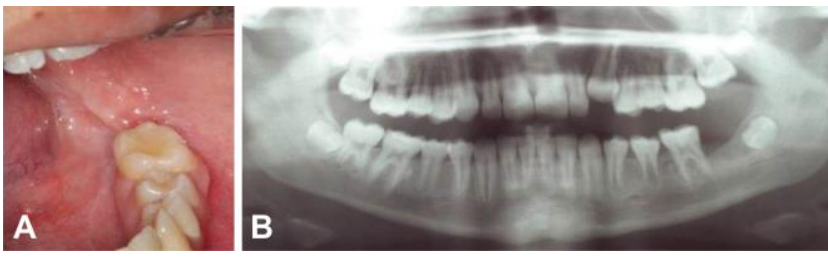

Figure 4: A. Postoperative follow-up intraoral view showing complete healing, and no sign of relapse.B. B. Postoperative panoramic radiograph showing alveolar bone healing, and a missing lower left second molar which was extracted concomitantly to excisional biopsy.

\section{RESULTS AND DISCUSSION}

IMT is a rare lesion that is part of a heterogeneous group of diseases with a broad phenotypic and biological spectrum. Such group encompasses both reactional lesions and benign neoplasms, the latter characterized by the proliferation of spindle cells, and a varying number of inflammatory cells ${ }^{3,5,6}$.

The etiology of IMT remains unclear, but factors such as trauma, infection by the Epstein-Barr virus, and alterations in the ALK gene have been associated with its occurrence $e^{2,7,8}$. This tumor has also been associated with human herpes virus 8 $(\mathrm{HHV}-8)$ as well as bacterial and fungal infections ${ }^{9}$. Moreover, there is a hypothesis that IMT can be related to some syndromes and autoimmune diseases such as Papillon-Lefevre, and severe congenital neutropenia (Kostmann's disease) ${ }^{3}$. Despite detailed interview, our patient reported no history of trauma, infection or syndrome that could be associated with the etiology of IMT.

IMT can affect the viscera and mucous membranes of subjects between 2 and 82 years of age, but it is more commonly diagnosed in children and young adults. Table 1 compares data obtained in this research with results observed by other authors $^{1,2,7,10-17}$. Females are known to be slightly 
more predisposed ${ }^{18,19}$. Although there is a predilection for the lungs and upper airways, the tumor can affect any area of the body, and appears clinically as a rapidly growing mass ${ }^{19}$. Binmadi et al. ${ }^{3}$ reported only 22 cases of oral IMT in the English literature, therein including his own publications on the topic. In the oral cavity, IMT commonly presents itself as a painless fast-growing swelling which is firm to the touch. All such features, in addition to focal ulceration, were present in the reported case. Signs of either bleeding or exudate were not observed.

IMT is characterized histologically as a proliferation of fibroblasts and myofibroblasts with a predominantly spindle morphology. These cells are permeated by an inflammatory infiltrate of mainly lymphocytes, plasma cells, and eosinophils ${ }^{11}$. Histological features consistent with aggressive behavior can lead IMT to mimic some malignant neoplasms. Therefore, it is very important to make a correct diagnosis to avoid burdensome and radical therapies. In this case report, the typical cellular components of IMT were present. Otherwise a diagnosis of malignant transformation would have been suggested.

Table 1. Distribution of IMT located in mandible according to age, gender and location

\begin{tabular}{|c|c|c|c|}
\hline Author & Age & Gender & Location \\
\hline Korlepara et al. $^{\top}$ & 22 & Male & Mandible \\
\hline Tateishi et al. $^{2}$ & 11 & Female & Mandible \\
\hline Stringer et al. ${ }^{7}$ & 16 & Male & Mandible \\
\hline Ide et al. ${ }^{10}$ & 43 & Female & $\begin{array}{l}\text { Mandible } \\
\text { (retromolar region) }\end{array}$ \\
\hline Jordan and Regezi ${ }^{11}$ & 23 & Male & Mandible \\
\hline Fang and Dym ${ }^{12}$ & 23 & Male & $\begin{array}{l}\text { Mandible } \\
\text { (retromolar region, } \\
\text { body and masseter } \\
\text { muscle) }\end{array}$ \\
\hline Brooks et al. ${ }^{13}$ & 82 & Female & Mandible \\
\hline Poh et al. ${ }^{14}$ & 42 & Female & Mandible \\
\hline Johann et al. $^{15}$ & 33 & Male & Mandible \\
\hline Oh et al. ${ }^{16}$ & 20 & Female & Mandible \\
\hline Palaskar et al. ${ }^{17}$ & 19 & Male & Mandible \\
\hline Present study & 12 & Male & Mandible \\
\hline
\end{tabular}

Due to its rare incidence and the difficulty in identifying myofibroblasts in specimens stained with hematoxylin and eosin, the diagnosis of IMT can be quite challenging. For that reason, immunohistochemistry should be considered as an important auxiliary tool in the correct diagnosis of myofibroblastic lesions. The spindle cells found in IMT are usually positive for vimentin, desmin, and alpha-smooth muscle actin $(\alpha \text {-SMA })^{20}$. However, there are variations in the percentage of lesions positive for Desmin. Investigations have shown that nearly 10 to $65 \%$ of the lesions are positive for this antibody ${ }^{20-22}$. Vimentin and $\alpha$-SMA were utilized in our study and the tumor was positive for both. Their expression indicates the presence of myofibroblastic ultrastructural components, thereby excluding the possibility of lymphoma, and other lymphoid lesions. IMT is often non-reactive to S-100 and CD34, and may react to anti-ALK ${ }^{23,24}$. Important, although ALK expression is reported in approximately $36 \%$ to $60 \%$ of IMTs, studies demonstrate that this antibody is not specific for this tumor and its expression may be seen in other neoplasms including rhabdomyosarcoma, lipogenic tumors, Ewing family tumors, undifferentiated pleomorphic sarcoma, and leiomyosarcoma ${ }^{22,25}$.

So far, IMT has been dealt with as a benign neoplasm. In fact, such a conservative approach has yielded very satisfactory results. Simple surgical excision has found to be quite effective and has not been associated with relapses whenever the lesion is completely excised. Other treatment modalities include radiotherapy, chemotherapy, curettage, and prescription of steroids. Even though our patient had no sign of malignancy or relapse, long-term monitoring was considered to be mandatory given the fact that IMT can sometimes behave as malignant tumors ${ }^{2}$. In our case, we chose to perform enucleation of the lesion. The patient has been followed up since then with no sign of recurrence after two years. Based on their own clinical experience, some researchers have stated that IMT of the head and neck can be treated conservatively, especially when located in the oral cavity and given a correct diagnosis. They also pointed out that such type of lesion usually has a better prognosis if compared with lesions located in other areas of the body ${ }^{26}$.

\section{CONCLUSION}

IMT is a benign neoplasm rarely found in the oral cavity. It has an unpredictable clinical behavior, thereby requiring total removal and continuous follow-up. There is no evidence of relapse, malignant transformation, metastasis or death related to oral IMT. Due to its clinical and radiographic aspects, it is possible to confuse IMT with some malignancies. Therefore, comprehensive pathological investigation is fundamental to make the correct diagnosis and establish a treatment whereby unnecessary surgical intervention that lead to functional impairments can be avoided.

\section{REFERENCES}

1. Korlepara R, Guttikonda VR, Madala J, Taneeru S. Inflammatory myofibroblastic tumor of mandible: A rare case report and review of literature. J Oral Maxillofac Pathol. 2017; 21(1):136-39.

2. Tateishi Y, Okudela K, Kawai S, Suzuki T, Umeda S, Matsumara $M$ et al. Intraosseous inflammatory myofibroblastic tumor of the mandible with a novel ATIC-ALK fusion 
mutation: a case report. Diagn Pathol. 2016; 11(1):132.

3. Binmadi NO, Packman H, Papadimitriou JC, Scheper M. Oral inflammatory myofibroblastic tumor: case report and review of literature. Open Dent J. 2011; 5:66-70.

4. Liston SL, Dehner LP, Jarvis CW, Pitzele C, Huseby TL. Inflammatory pseudotumors in the buccal tissues of children. Oral Surg Oral Med Oral Pathol. 1981; 51(3):287-91.

5. Coffin CM, Humphrey PA, Dehner LP. Extrapulmonary inflammatory myofibroblastic tumor: a clinical and pathological survey. Semin Diagn Pathol. 1998; 15(2):85-101.

6. Xavier FC, Rocha AC, Sugaya NN, dos SantosPinto D Jr, de Sousa SC. Fibronectin as an adjuvant in the diagnosis of oral inflammatory myofibroblastic tumor. Med Oral Patol Oral Cir Bucal. 2009; 14(12):e635-39.

7. Stringer DE, Allen CN, Nguyen K, Tandon R. Intraosseous inflammatory myofibroblastic tumor in the mandible: a rare pathologic case report. Case Rep Surg. 2014; 2014: 565478.

8. Guilemany JM, Alós L, Alobid I, BernalSprekelsen M, Cardesa A. Inflammatory myofibroblastic tumor in the larynx: clinicopathologic features and histogenesis. Acta Otolaryngol. 2005; 125(2):215-19.

9. Lizarbe MO, Olascoaga JH, García ER, Castiella TM, Sagaseta de Ilúrdoz Uranga María M, Garicano JM. Paediatric myofibroblastic tumours. A presentation of three cases. An Pediatr (Barc). 2009; 71(4):331-35.

10.Ide F, Shimoyama T, Horie N. Inflammatory pseudotumor in the mandibular retromolar region. J Oral Pathol Med. 1998; 27(10):508-10.

11.Jordan RC, Regezi JA. Oral spindle cell neoplasms: a review of 307 cases. Oral Surg Oral Med Oral Pathol Oral Radiol Endod. 2003; 95(6):717-24.

12.Fang JC, Dym H. Myofibroblastic tumor of the oral cavity. A rare clinical entity. NY State Dent J. 2004; 70(3):28-30.

13. Brooks JK, Nikitakis NG, Frankel BF, Papadimitriou JC, Sauk JJ. Oral inflammatory myofibroblastic tumor demonstrating ALK, p53, MDM2, CDK4, pRb, and Ki-67 immunoreactivity in an elderly patient. Oral Surg Oral Med Oral Pathol Oral Radiol Endod. 2005; 99(6):716-26.

14.Poh CF, Priddy RW, Dahlman DM. Intramandibular inflammatory myofibroblastic tumor--a true neoplasm or reactive lesion? Oral Surg Oral Med Oral Pathol Oral Radiol Endod. 2005; 100(4):460-66.

15.Johann AC, Caldeira PC, Abdo EN, Sousa SO, Aguiar MC, Mesquita RA. Inflammatory myofibroblastic tumor of the alveolar mucosa of the mandible. Minerva Stomatol. 2008; 57(1-2):59-63.

16. Oh JH, Yim JH, Yoon BW, Choi BJ, Lee DW, Kwon YD. Inflammatory pseudotumor in the mandible. J Craniofac Surg. 2008; 19(6):1552-53.

17.Palaskar S, Koshti S, Maralingannavar M, Bartake A. Inflammatory myofibroblastic tumor. Contemp Clin Dent. 2011; 2(4):274-77.

18. Kim SY, Yang SE. Inflammatory myofibroblastic tumor of the maxillary sinus related with pulp necrosis of maxillary teeth: case report. Oral Surg Oral Med Oral Pathol Oral Radiol Endod. 2011; 112(5):684-87.

19.Lourenço SV, Boggio P, Simonsen Nico MM. Inflammatory myofibroblastic tumor of the tongue: report of an unusual case in a teenage patient. Dermatol Online J. 2012; 18(5):6.

20.Coffin CM, Watterson J, Priest JR, Dehner LP. Extrapulmonary inflammatory myofibroblastic tumor (inflammatory pseudotumor). A clinicopathologic and immunohistochemical study of 84 cases. Am J Surg Pathol. 1995; 19(8):859-72.

21.Meis JM, Enzinger FM. Inflammatory fibrosarcoma of the mesentery and retroperitoneum. A tumor closely simulating inflammatory pseudotumor. Am J Surg Pathol. 1991; 15(12):1146-56.

22. Goldblum JR, Weiss SW, Folpe AL. Enzinger and Weiss's soft tissue tumors. 6th ed. Philadelphia, PA: Saunders/Elsevier; 2014.

23.Swain RS, Tihan T, Horvai AE, Di Vizio D, Loda $\mathrm{M}$, Burger PC et al. Inflammatory myofibroblastic tumor of the central nervous system and its relationship to inflammatory pseudotumor. Hum Pathol. 2008; 39(3):410-19.

24.Ong HS, Ji T, Zhang CP, Li J, Wang LZ, Li RR. Head and neck inflammatory myofibroblastic tumor (IMT): evaluation of clinicopathologic and prognostic features. Oral Oncol. 2012; 48(2):141-48.

25.Cessna MH, Zhou H, Sanger WG, Perkins SL, Tripp S, Pickering D et al. Expression of ALK1 and p80 in inflammatory myofibroblastic tumor and its mesenchymal mimics: a study of 135 cases. Mod Pathol. 2002; 15(9):931-38.

26.Pankaj C, Uma C. How to manage oral inflammatory myofibroblastic tumor (inflammatory pseudotumor)? Oral Dis. 2001; 7(5):315-16. 


\section{CONFLITS OF INTERESTS}

The authors declare no conflicts of interests.

\section{CORRESPONDING AUTHOR}

\section{Hellen Bandeira de Pontes Santos}

hellenbps@hotmail.com

Received 27/05/2018

Accepted 27/06/2018 